Review article

\title{
Use of antimicrobials in veterinary medicine and mechanisms of resistance
}

\author{
Stefan SCHWARZ $^{\text {a* }}$, Elisabeth CHASLUS-DANCLA ${ }^{\text {b }}$ \\ a Institut für Tierzucht und Tierverhalten, Bundesforschungsanstalt für Landwirtschaft (FAL), \\ Dörnbergstr. 25-27, 29223 Celle, Germany \\ b Institut National de la Recherche Agronomique, Pathologie Aviaire et Parasitologie, \\ 37380 Nouzilly, France
}

(Received 18 December 2000; accepted 14 February 2001)

\begin{abstract}
This review deals with the application of antimicrobial agents in veterinary medicine and food animal production and the possible consequences arising from the widespread and multipurpose use of antimicrobials. The various mechanisms that bacteria have developed to escape the inhibitory effects of the antimicrobials most frequently used in the veterinary field are reported in detail. Resistance of bacteria to tetracyclines, macrolide-lincosamide-streptogramin antibiotics, $\beta$-lactam antibiotics, aminoglycosides, sulfonamides, trimethoprim, fluoroquinolones and chloramphenicol/florfenicol is described with regard to enzymatic inactivation, decreased intracellular drug accumulation and modification/protection/replacement of the target sites. In addition, basic information is given about mobile genetic elements which carry the respective resistance genes, such as plasmids, transposons, and gene cassettes/integrons, and their ways of spreading via conjugation, mobilisation, transduction, and transformation.
\end{abstract}

antibiotic therapy / growth promotion / resistance mechanism / resistance gene / gene transfer

Résumé - Utilisation d'agents antimicrobiens en médecine vétérinaire et mécanismes de résistance. Cette revue présente les différents buts pour lesquels les agents antimicrobiens sont utilisés en médecine vétérinaire, dans les élevages d'animaux entrant dans la chaîne alimentaire et les possibles conséquences de cette large utilisation. Une synthèse est faite des différents mécanismes de résistance développés par les bactéries, comme l'inactivation enzymatique, la diminution de la concentration intracellulaire de l'antibiotique, les modification/protection/déplacement de cible, qui permettent d'échapper à l'action des antibiotiques les plus fréquemment utilisés dans le domaine vétérinaire : tétracyclines, macrolide-lincosamide-streptogramine, $\beta$-lactamines, aminosides, sulfamides, triméthoprime, fluoroquinolones et chloramphénicol/florfénicol. Le rôle d'éléments génétiques mobiles

* Correspondence and reprints

Tel.: (49) 5141 384673; fax: (49) 5141 381849; e-mail: stefan.schwarz@fal.de 
portant les gènes de résistance tels que les plasmides, les transposons ou les cassettes/intégrons, et leur mode de diffusion par conjugaison, mobilisation ou transduction sont présentés.

traitement antibiotique / promoteur de croissance / mécanisme de résistance / gène de résistance / transfert de gène

Table of contents

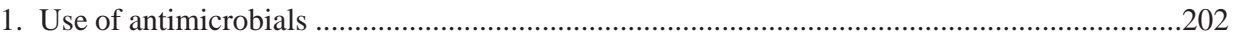

1.1. Different aims for the use of antibiotics in food-producing animals ...............................202

1.2. Volumes of antimicrobials used for animals in Europe..................................................204

1.3. Particularities of usage in animals and classes of antibiotics used in animals.................206

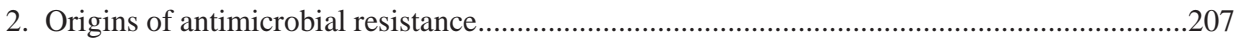

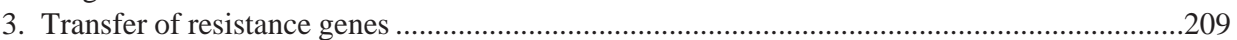

3.1. Elements involved in the horizontal transfer of resistance genes ....................................209

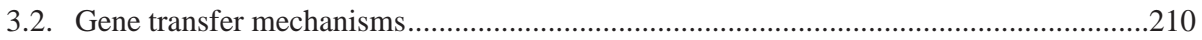

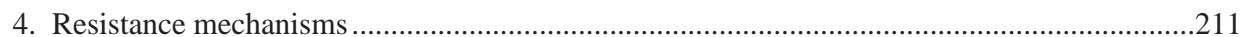

5. Resistance to antimicrobials used in veterinary medicine ..................................................213

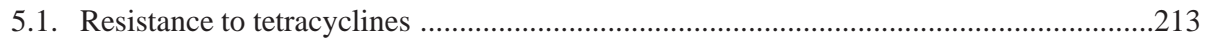

5.2. Resistance to macrolides, lincosamides, and streptogramins (MLS) .............................216

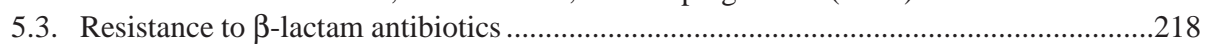

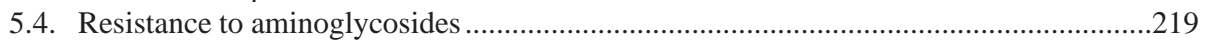

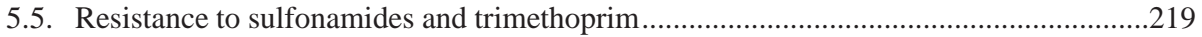

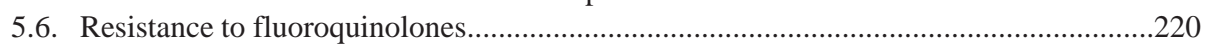

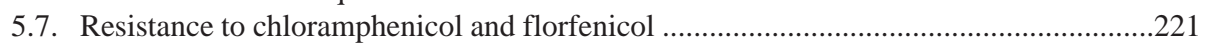

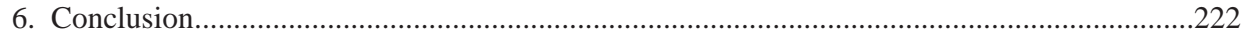

\section{USE OF ANTIMICROBIALS}

\subsection{Different aims for the use of antibiotics in food-producing animals}

Unlike in human medicine, antibiotics in food-producing animals are used for two different purposes: (a) prevention and control of bacterial infections and (b) growth promotion [63].

The control and prevention of bacterial infections is achieved by either therapeutic, metaphylactic or prophylactic application of antimicrobials. For this, substances of mainly the same classes as used in human medicine are available for the treatment of food-producing animals - the antimicrobials available in the different European countries are listed in Table I. The purpose of therapy is to treat a declared infection. According to the number of animals present and the type of production, these treatments may be individual as in pet and companion animals, dairy cattle, horses and sows, and given by oral or parenteral ways. Nevertheless, in most cases, when large groups of animals have to be treated, as in poultry or swine production, they are applied via water or feed. With such mass production, when a limited number of animals have been identified as infected, rapid treatment of all animals of the respective group/herd/ flock is necessary to prevent further extension of the infection. This is referred to as metaphylaxis [63]. In addition to these interventions, prophylaxis is a solely preventive measure, given individually or to groups of animals, which appears unavoidable under 


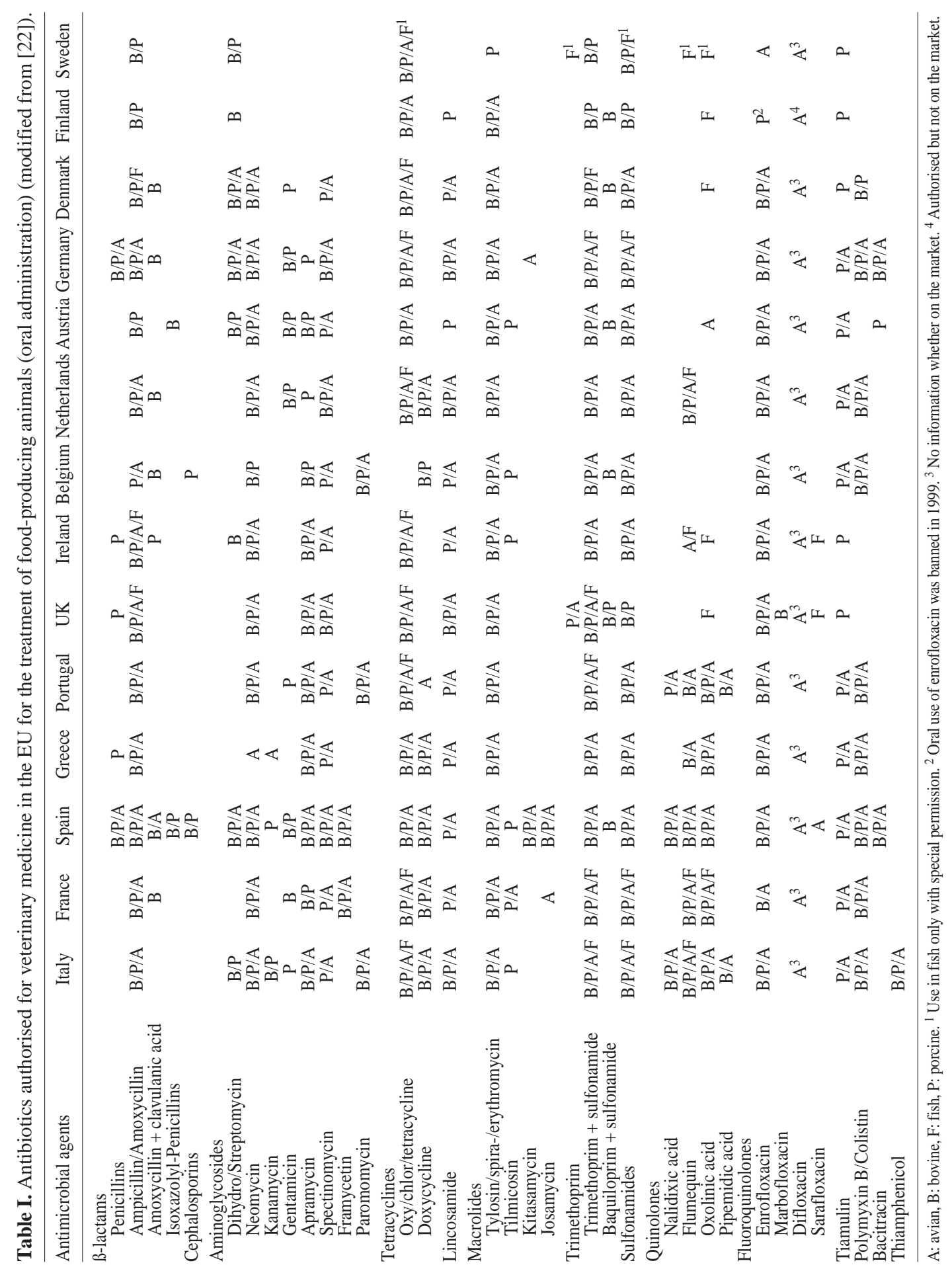


certain circumstances and in some key periods of animal life, such as surgery, vaccination, transport and mixing of animals, weaning of pigs, and the end of lactation in dairy cows. During such periods, animals are generally recognised as more susceptible to infections and long-term experience with the current animal production systems requires the application of antimicrobials at such times to avoid the onset of infections. Without these preventive treatments, subsequent clinical infections would occur more frequently and would require more therapeutic interventions for an efficient control. However, prophylactic application of antimicrobials is criticised for its possible involvement in the selection of resistant bacteria and the promotion of the spread of resistance genes [63].

The second purpose of the use of antibiotics, growth promotion, is specific to foodproducing animals. A specified number of substances licensed as growth promoters are given at low concentrations to improve growth during the entire growth period of animals. The available molecules and conditions of use are clearly defined in licences specifying the target animals, duration, and dosage. In Europe, since 1975, no $\beta$-lactams or tetracyclines have been used as growth promoters whereas they are still in use in the USA. Recent discussions at the European level have resulted in a limited list of four drugs available for this purpose. Indeed, all drugs similar or closely related to those used for human therapy, such as the glycopeptide avoparcin, the macrolides tylosin and spiramycin, the streptogramin virginiamycin, and the polypeptide $\mathrm{Zn}$-bacitracin, were banned or withdrawn in 1998 and 1999. In addition, the quinoxalines carbadox and olaquindox, were withdrawn in 1999 for possible toxicological effects. Currently, the four available molecules are flavophospholipol, monensin-Na, salinomycin-Na, and avilamycin. Only two of them (flavophospholipol, avilamycin) have a real antibiotic activity. The remaining two substances are used for their coccidiostatic effects [63]. The situation regarding avilamycin was critical as it is structurally related to everninomycin that was then being developed for human therapy. However, information was given in May 2000 by the company, Schering-Plough, concerning the ending of further development of everninomycin. In the present situation, all the antimicrobial growth promotors used are expected to develop no cross-resistance with molecules used for human medicine.

\subsection{Volumes of antimicrobials used for animals in Europe}

In most countries except Denmark, Sweden and Finland, no legal obligation exists for pharmaceutical companies to supply data on antibiotic sales. Thus it is very difficult to have a precise knowledge of the volumes of antibiotics sold in Europe. Such data for the year 1997 were available for the first time from the European federation for animal health (Fedesa) after being requested by the European Commission to provide information on the actual usage of antibiotics in the EU including Switzerland [6]. Extrapolation factors were needed for each country to obtain the total amount of antibiotics sold taking into account estimations of sales by non-Fedesa members. The respective data for 1997 are available on the internet (http://www.fedesa.be/eng/ PublicSite/xtra/dossiers/doss9/).

The world-wide use of antibiotics for animal health purposes in 1996 was estimated at 27000 tonnes of which about $25 \%$ was used throughout the EU. In the EU, an estimated distribution was given as $50 \%$ for therapeutic purposes, $25 \%$ feed additive usage and the $25 \%$ remaining for ionophore feed additives to prevent coccidiosis in poultry [6]. Ninety percent of all the antibiotics (including those used for growth promotion and those for therapy) produced in the world for animal use are distributed via feed. They are mainly used for pigs (60\%), poultry and 
rabbits $(20 \%)$, ruminants $(18 \%)$, fish $(1 \%)$, and pets (1\%) [7].

In Europe, in 1997, the total sales volumes of antibiotics was 10493 tonnes of active ingredients, which can be subdivided into $5400 \mathrm{t}$ for human health usage (52\%), $3494 \mathrm{t}$ for animal health use (33\%), and $1599 \mathrm{t}$ for growth promotion (15\%).

High differences in percentages of drugs used for therapy or growth promotion exist between the different countries in relation to the type of animal production, whether intensive or not (Tabs. II and III).

It was interesting to further analyse relationships between the amounts of antibiotics used in each class of livestock and the number of animals produced per country. For 1997, this comparison was difficult as the animal production data were available for 1996 only, as sales data for 1997 were

Table II. Sales volumes of antimicrobial agents (therapeutics and growth promoters) in different EU member states in 1997 (adapted from [22]).

\begin{tabular}{|c|c|c|c|c|}
\hline \multirow[t]{2}{*}{ Country } & \multicolumn{2}{|c|}{$\begin{array}{l}\text { Sales } \\
\text { of growth promoters }\end{array}$} & \multicolumn{2}{|c|}{$\begin{array}{c}\text { Sales } \\
\text { of therapeutics }\end{array}$} \\
\hline & $\begin{array}{c}\text { Tonnes of } \\
\text { active } \\
\text { substances }\end{array}$ & $\begin{array}{l}\% \text { of the EU } \\
\text { market }\end{array}$ & $\begin{array}{c}\text { Tonnes of } \\
\text { active } \\
\text { substances }\end{array}$ & $\begin{array}{c}\% \text { of the EU } \\
\text { market }\end{array}$ \\
\hline Austria & 23 & 1 & 8 & $<1$ \\
\hline Belgium-Luxembourg & 110 & 7 & 125 & 4 \\
\hline Denmark & 75 & 5 & 60 & 2 \\
\hline Finland & $<1$ & $<1$ & 12 & $<1$ \\
\hline France & 339 & 21 & 492 & 14 \\
\hline Germany & 255 & 16 & 488 & 14 \\
\hline Greece & 15 & 1 & 110 & 3 \\
\hline Ireland & 34 & 2 & 22 & $<1$ \\
\hline Italy & 100 & 6 & 389 & 11 \\
\hline The Netherlands & 226 & 14 & 300 & 9 \\
\hline Portugal & 24 & 2 & 44 & 1 \\
\hline Spain & 198 & 12 & 616 & 18 \\
\hline Sweden & $<1$ & $<1$ & 20 & $<1$ \\
\hline UK & 191 & 12 & 788 & 23 \\
\hline
\end{tabular}

Table III. Sales volumes of antimicrobial agents in the EU and Switzerland in 1997 (adapted from [22]).

\begin{tabular}{lcc}
\hline Classes of antimicrobials & \multicolumn{2}{c}{ Sales as estimated by FEDESA } \\
\cline { 2 - 3 } & Tonnes of active substances & \% of total \\
\hline Tetracyclines & 2294 & 66 \\
Macrolides & 424 & 12 \\
Penicillins & 322 & 9 \\
Aminoglycosides & 154 & 4 \\
Trimethoprim/sulfonamides & 75 & 2 \\
Fluoroquinolones & 43 & 1 \\
Other classes & 182 & 5 \\
\hline
\end{tabular}


estimated. Nevertheless, animal production in 1997 was expected to be similar to 1996. Another difficulty was that data on farm animal production numbers are available from an annual consensus within all member states and represent calculations of animal numbers on a certain day and not the total number of animals raised in one year. In contrast, production data (slaughtered animals, milk/egg production) are calculated on a yearly basis. Carcass weights of particular animals at slaughter considerably differ in the countries of the EU according to the type of production and consumer preferences.

Although based on an estimation, the results of comparisons made it possible to classify countries into three groups: countries with the highest level of antibiotics (therapeutic and growth promotion) used by tonne of live weight of slaughtered animal, which are the UK, Greece, Spain and The Netherlands, countries with an intermediate position such as Belgium, France, Italy, Germany and Portugal, and finally countries with a low ratio such as Sweden, Denmark, Finland. This classification largely reflects the type of husbandry system.

Another relevant analysis could be the comparison of the consumption of antibiotics in human and veterinary medicine. As this comparison could not be performed on the basis of a calculation per head and per year as the lives of several animals are shorter than one year, the sales volumes and body mass were compared instead [72]. From the evaluation of the animal production data obtained for 1996, including animals at slaughter and animals for milk and egg production, the body mass of 6.1 billion farm animals could be calculated as 51.5 billion tonnes to which the consumption of $54 \mathrm{mg}$ antibiotic per $\mathrm{kg}$ can be related. Similar data were expected for the year 1997. In 1997, the European population was of 373 million inhabitants with a mean individual body weight of $60 \mathrm{~kg}$ to which the 54000 tonnes used in human medicine could be related. The corresponding calcu- lated dose was of $241 \mathrm{mg}$ per $\mathrm{kg}$ body weight which is 4.5 -fold higher than in veterinary medicine [72]. Nevertheless, this is only a rough estimation, as different parameters appear to be under- or overestimated, for instance, in human medicine not all the antibiotics sold are totally consumed.

\subsection{Particularities of usage in animals and classes of antibiotics used in animals}

An important aspect which is specific to veterinary medicine is the problem of residues in carcasses at slaughter. This problem has been taken into account and European legislation was recently revisited in order to provide safe products to consumers. For each antibiotic used, the Maximum Residue Level (MRL) had to be defined before licensing, that is the maximum level of antibiotic residue acceptable in carcasses at slaughter without any adverse effect on public health [79]. In toxicological and microbiological studies, this non-observed effect level (NOEL) is generally taken as the dose at and below which adverse effects do not occur. EU legislation was introduced in two steps: as from January 1992, new active ingredients or pharmaceutically active excipients could be introduced onto the markets of the Member States after definition of a Community MRL, and the substances already in use at that date were subject to a systematic call-up in order to establish the MRL. For these molecules already in use, the initial deadline, 1997, had to be postponed. In such conditions, Community MRLs for veterinary drugs were established for different purposes: (a) as a guarantee for consumers of safe foodstuffs, (b) as a basis for the definition of withdrawal periods (periods between the end of a treatment and the arrival of carcasses at slaughter), and (c) as standards for residue surveillance and trade.

The calculation of MRL was based on the NOEL found in toxicological and 
microbiological studies on sensitive animal species. Extrapolation to humans (standard human body weight of $60 \mathrm{~kg}$ ) was based on the acceptable daily intake or daily dose, which was calculated from the NOEL by dividing it by a safety factor (100 to 1000). Distribution of the daily dose in the different foods was then evaluated taking into account the average consumption of the representative European man of $60 \mathrm{~kg}$, which is stated to include: meat (300 g), liver (100 g), fat (50 g), milk (1.5 L), and eggs (100 g). As a consequence, some drugs such as nitroimidazoles (1993), chloramphenicol (1994), and furazolidones (1995) were withdrawn at the European level for use in food-producing animals.

Although antibiotics used for therapy/methaphylaxis or for prophylaxis belong to the same classes as those used for human therapy, relevant differences exist within classes and some particularities of the veterinary pharmacopoeia compared to the human pharmacopoeia can be listed:

(i) In veterinary medicine, the cost of a course of treatment has to be taken into account. For economic reasons, old but still efficient molecules are largely used such as penicillins and tetracyclines. In 1997, among the 3494 tonnes of antibiotics (active ingredients) used for therapy in animals, the top three were tetracyclines, macrolides, and penicillins (Tab. III).

(ii) In veterinary medicine, some families are under-developed in comparison to their relatives currently in human use. In France, among cephalosporins, only two molecules of third generation, ceftiofur and cefquinome, are used in cattle in injections or intra-mammary infusions.

(iii) A very limited number of new molecules have been introduced into veterinary medicine over the last decades, including tiamuline, florfenicol, a fluorinated derivative of chloramphenicol (1995), and fluoro- quinolones. Quinolones represent 1\% of the antibiotics used. As regards oral use in all types of animals, nalidixic acid is maintained in three countries only - Italy, Spain, and Portugal - and flumequin or oxolinic acid are licensed in most countries except Germany. The recently introduced fluoroquinolones, enrofloxacin, marbofloxacin, difloxacin or danofloxacin are used in most countries. Sarafloxacin is limited to fish and has been introduced in the UK and Ireland only, and orbifloxacin used exclusively in pets in the UK [22].

(iv) Some molecules have been introduced into veterinary medicine only, such as the aminoglycoside apramycin, florfenicol, tylosin, tilmicosine and tiamuline.

(v) Some molecules recently introduced in human medicine have not been introduced in animal therapy, as for instance, the third generation of cephalosporins, amikacin, or minocyline. In addition, promising new classes of antimicrobials, such as ketolides, glycylcyclines or oxazolidinones which are currently under development or in clinical trials will be exclusively reserved for human therapy.

\section{ORIGINS OF ANTIMICROBIAL RESISTANCE}

Most antimicrobial agents currently used in human and veterinary medicine are low molecular weight substances which inhibit growth of bacteria or even kill them at very low concentrations. The first antimicrobials used represented substances or close relatives of substances which were produced by fungi or soil bacteria and provided a selective advantage to the antimicrobial producer in the fight for resources and ecological niches. Thus bacteria have come into contact with antimicrobial substances a long time before the first antimicrobial agents were introduced into clinical use. 
Admittedly, this contact between antimicrobial substances and sensitive microorganisms in the pre-antibiotic era occurred at a distinctly lower frequency than nowadays. Nevertheless, it represented a selective pressure which in return forced microorganisms to develop mechanisms to escape the inhibitory activities of antimicrobial agents. There are mainly three ways in which bacteria gain resistance to antimicrobial agents. One way is for bacteria to acquire resistance genes from the antibiotic producers and modify them with a view to optimising functionality in the new host. The resistance genes that antibiotic producers harbour as a mechanism of selfdefence from their own products are usually located in the chromosomal DNA. Their spread to other bacteria must therefore involve the integration of these genes into mobile genetic elements such as plasmids and transposons, both of which have been detected in bacteria collected in the preantibiotic era. When such resistance genes are transferred across species and even genus borders, they may undergo mutations in their new hosts resulting in a wide variety of structurally heterogeneous, but functionally homologous resistance determinants. Examples of such a divergent evolution from a common ancestor are the efflux proteins associated with tetracycline resistance in gram-positive and gram-negative bacteria [52]. The second way to develop resistance genes is a stepwise mutation of genes whose products play a role in physiological cell metabolism. As a result, genes are modified in a way that the substrate spectrum of their products changes from metabolites of biosynthetic or biodegradative pathways to certain antimicrobial agents only. The various enzymes exhibiting acetyl-, adenyl- or phosphotransferase activities involved in the inactivation of aminoglycosides or chloramphenicol are believed to have evolved this way [19]. A third major way for bacteria to gain resistance is to modify their target structures by either single-step (streptomycin resistance) or multi-step mutations (fluoroquinolone resistance), so that they become resistant to the inhibitory effects of the respective antimicrobials [2].

As a result of the exposure of bacteria to antimicrobial agents, a large number of resistance genes has developed. The observation that the introduction of an antimicrobial into clinical use has been either accompanied or followed shortly by the occurrence of bacteria which are resistant to this particular substance (Tab. IV) underlines the extraordinary capacity of bacteria to quickly and efficiently respond to the selective pressure imposed by the use of that substance. In recent years, bacteria have also developed resistance to completely synthetic substances which have no natural counterpart. This finding confirms the stunning ability of bacteria to cope with changed environmental

Table IV. Time coincidence between the discovery/production of antimicrobial agents, their introduction into clinical use as well as the occurrence of resistant bacteria (modified according to [22]).

\begin{tabular}{lccc}
\hline Antimicrobial agent & $\begin{array}{c}\text { Discovery / } \\
\text { production }\end{array}$ & $\begin{array}{c}\text { Introduction into } \\
\text { clinical use }\end{array}$ & $\begin{array}{c}\text { Occurrence of } \\
\text { resistant bacteria }\end{array}$ \\
\hline Penicillin & 1940 & 1943 & 1940 \\
Streptomycin & 1944 & 1947 & 1947,1956 \\
Tetracycline & 1948 & 1952 & 1956 \\
Erythromycin & 1952 & 1955 & 1956 \\
Vancomycin & 1956 & 1972 & 1987 \\
Nalidixic acid & 1960 & 1962 & 1966 \\
Gentamicin & 1963 & 1967 & 1970 \\
Fluoroquinolones & 1978 & 1982 & 1985 \\
\hline
\end{tabular}


conditions and to effectively explore a wide variety of ways to survive even in the presence of toxic substances such as antimicrobial agents [5]. The exchange of resistance genes between members of a mixed bacterial population has distinctly accelerated the widespread occurrence of certain resistance genes in a large number of pathogenic bacteria, but also in harmless commensals. Resistance genes were usually first present in the bacteria in which they had evolved and were initially only transmitted vertically. However when integrated into mobile genetic elements, the resistance genes were spread by horizontal transfer among bacteria of the same and of different species and genera. Thus the driving forces of emerging antimicrobial resistance are repeated exposure of the bacteria to antibiotics and access of the bacteria to a large resistance gene pool as the latter is available in a polymicrobial environment.

\section{TRANSFER OF RESISTANCE GENES}

\subsection{Elements involved in horizontal transfer of resistance genes}

The rapid spread of antimicrobial resistance genes between bacteria of the same and of different species and genera is mainly the result of horizontal transfer events of mobile genetic elements carrying one or more resistance genes. Among them, plasmids, transposons and integrons/gene cassettes play a major role. These three types of elements are composed of double-stranded DNA, but differ distinctly in their sizes, structures, biological properties as well as ways of spreading.

Plasmids are extrachromosomal elements which have been detected in virtually all bacterial genera of medical or veterinary importance, but also in bacteria which constitute the physiological flora of the skin and the various mucosal surfaces in humans and animals. Their size varies from less than 2 kilobase pairs (kbp) to more than $100 \mathrm{kbp}$. Plasmids are capable of autonomous replication due to their replication systems. As long as plasmids belong to different incompatibility groups, they can stably coexist in the same bacterial cell. Plasmid-borne properties are not essential for the survival of the bacteria under physiological conditions, but may be of benefit for the bacterium under specific conditions. These accessory properties include resistance to antimicrobial agents, disinfectants, heavy metal cations, anions, nucleic acid binding substances or bacteriocins. In addition to resistance properties, various other traits are known to be plasmid-borne, such as metabolic properties, virulence properties, and fertility functions [68]. Plasmids can carry one or more resistance gene(s) in addition to genes coding for other of the above-mentioned functions. Plasmids may form cointegrates with other plasmids, may integrate or be integrated, either in part or in toto, into the chromosomal DNA or can act as vectors for transposons and integrons/gene cassettes [5]. Large plasmids can carry genes (tra gene complex) which enable them to move on their own from one host cell to another. Such plasmids are referred to as conjugative plasmids.

In contrast to plasmids, transposons do not possess replication systems and therefore must integrate for their stable maintenance into replication-proficient vector molecules such as chromosomal DNA or plasmids in the cell. Transposons also vary in size ( $<1 \mathrm{kbp} \rightarrow 60 \mathrm{kbp})$ and structure. The smallest transposons, also known as insertion sequences, solely carry the gene for a transposase which is responsible for the movement of the element. Larger transposons usually carry one or more additional genes, most of which code for antibiotic resistance properties. Many transposons have little or no target specificity and therefore can insert themselves at various positions in the chromosomal or plasmid DNA. 
Large conjugative transposons may also harbour tra genes [2, 4].

Gene cassettes represent small mobile elements of less than $2 \mathrm{kbp}$ and, to date, have only been detected in gram-negative bacteria [51]. They commonly consist of only a specific recombination site and a single gene which is in most known cases an antimicrobial resistance gene. Gene cassettes differ from plasmids by the lack of replication systems, and from transposons by the lack of transposition systems. They move by site-specific recombination. They are usually present at specific sites within an integron. Integrons most often represent intact or defective transposons and commonly consist of two conserved regions, one of which, the 5' conserved region, codes for the integrase that is responsible for the site-specific insertion of the gene cassettes and also harbours the promoter for the expression of the cassette-borne genes. The 3 ' conserved region may represent another resistance gene, such as the sulfonamide resistance gene sulI [51]. The role of integrons in the diffusion of resistance was reviewed by Carattoli [10].

\subsection{Gene transfer mechanisms}

Plasmids, transposons and gene cassettes/integrons are spread vertically during the division of the host cell, but can also be transferred horizontally between bacteria of the same or different species and genera via transduction, conjugation/mobilisation or transformation $[5,61]$.

Transduction describes a bacteriophagemediated transfer process. Bacteriophages are also referred to as "bacterial viruses". They infect bacteria by injection of their DNA. In the new host cell, the phage DNA can direct the production of new phage particles which includes expression of phageborne genes, replication of the phage DNA and packaging of this DNA into new phage particles which are released from the bacterial cell (lytic cycle). On the other hand, the phage DNA may integrate into the chromosomal DNA of the host cell as a "prophage" and remain there for long periods in an inactive state (lysogenic cycle). External factors such as UV-irradiation can activate the prophage and initiate a lytic cycle. Chromosomal resistance genes that are located close to the integration site of the prophage may become part of the phage genome when the prophage is not excised precisely from the chromosomal DNA. In this case, the resistance genes spread with the phage particles to new host cells. During phage assembly, resistance plasmids may accidentally be packaged into phage heads instead of phage DNA. The resulting "pseudophages" are able to infect new host cells as the regular phages do. However, since they lack phage DNA, they can only inject the plasmid DNA and thus promote the spread of resistance plasmids to new host cells. The spread of resistance genes via transduction is strongly influenced by the limited amount of DNA that can be packaged into a phage head and the requirement of specific receptors for phage attachment on the surface of the new host cell. For staphylococci, it has been reported that $45 \mathrm{kbp}$ is the upper size limit of DNA that can be transduced. While smaller plasmids are transduced as linear concatemers, larger plasmids cannot be packaged into a phage head. Since only host cells that are phylogenetically closely related carry the same receptors for phage attachment, transduction is commonly observed between bacteria of the same species, but rarely seen between bacteria of different species and genera. Transducing phages have been detected in a wide variety of bacteria [34].

Conjugation describes the self-transfer of a conjugative plasmid or transposon from a donor cell to a recipient cell [5]. Close contact between donor and recipient is one of the major requirements for efficient conjugation. The tra gene complex whose gene products represent components of the transfer apparatus spans at least $15 \mathrm{kbp}$ in gram-positive bacteria and $30 \mathrm{kbp}$ in 
gram-negative bacteria and thus cannot be located on small resistance plasmids commonly seen among bacterial pathogens. Small non-conjugative plasmids which coreside in the same host cell may use the transfer apparatus provided by the conjugative element, as long as they have an ori $\mathrm{T}$ region (origin of transfer) but possibly also possess mobilisation ( $m o b)$ genes. This process is known as mobilisation. Conjugation and mobilisation are believed to be of major importance for the spread of resistance genes between bacteria of different species and genera in bacterial mixed populations as seen on the skin and mucosa of the alimentary, respiratory, and genital tract of humans and animals. So far, conjugative plasmids and transposons carrying one or more antibiotic resistance genes have been reported to be present in gram-positive and gram-negative bacterial pathogens [60].

Transformation describes the transfer of free DNA into competent recipient cells. Transformation is the major way of introducing plasmids into new host bacteria under in vitro conditions. Under in vivo conditions, transformation is considered to play only a limited role in the transfer of resistance genes [5]. On the one hand, free DNA originating from lysed bacteria is usually rapidly degraded under most environmental conditions. On the other hand, only a few bacteria, such as Streptococcus pneumoniae or Bacillus spp., exhibit a natural ability to take up DNA from their environment.

\section{RESISTANCE MECHANISMS}

A bacterium is considered to be resistant to an antimicrobial agent when the concentration of the antimicrobial agent at the site of infection is not sufficiently high to either inhibit replication of the bacterium or even kill it [78]. This definition clearly shows that antimicrobial resistance is not solely a microbiological problem, but also includes pharmacological, pharmacokinetic and clinical aspects. Antimicrobial resistance is a highly flexible property of the bacteria which varies with respect to the antimicrobial agents, the respective bacteria and the resistance mechanism. Up to six different mechanisms have been described as conferring resistance to the same antimicrobial agent. Some resistance mechanisms are distributed among a wide variety of bacteria, while others appear to be specific for certain bacterial species and genera. In contrast to genus- or species-specific intrinsic resistance properties which are mainly based on either the lack of or the inaccessibility of the target sites for the antimicrobial agents, acquired resistance properties account for most of the resistance problems currently encountered in human and veterinary medicine. Acquired resistance represents a strain-specific property which may be based on mutations in certain chromosomal "housekeeping" genes which act as targets for antimicrobial agents. Such mutations are mainly based on the exchange of one or a few bases and consequently cause only slight changes in the amino acid sequence of the corresponding gene product. These sequence alterations often have little or no influence on the biological activity of the gene products, but render them insensitive to the inhibitory activities of the respective antimicrobial agents [2, 48]. Acquired resistance, however, is more often associated with the acquisition of mobile genetic elements that carry one or more resistance genes [2, 5]. Such resistance genes code for proteins which do not usually have a known function in physiological cell metabolism, but mediate resistance to either single antimicrobial substances or members of the same class of substances (e.g. tetracyclines). They can also mediate resistance to members of different classes of antimicrobials which, however, have the same target site within the bacterial cell (e.g. macrolides, lincosamides and B-compounds of the streptogramins). In the case of multidrug transporter systems which export toxic metabolites from the cell, resistance to structurally and functionally different antibiotics, often 


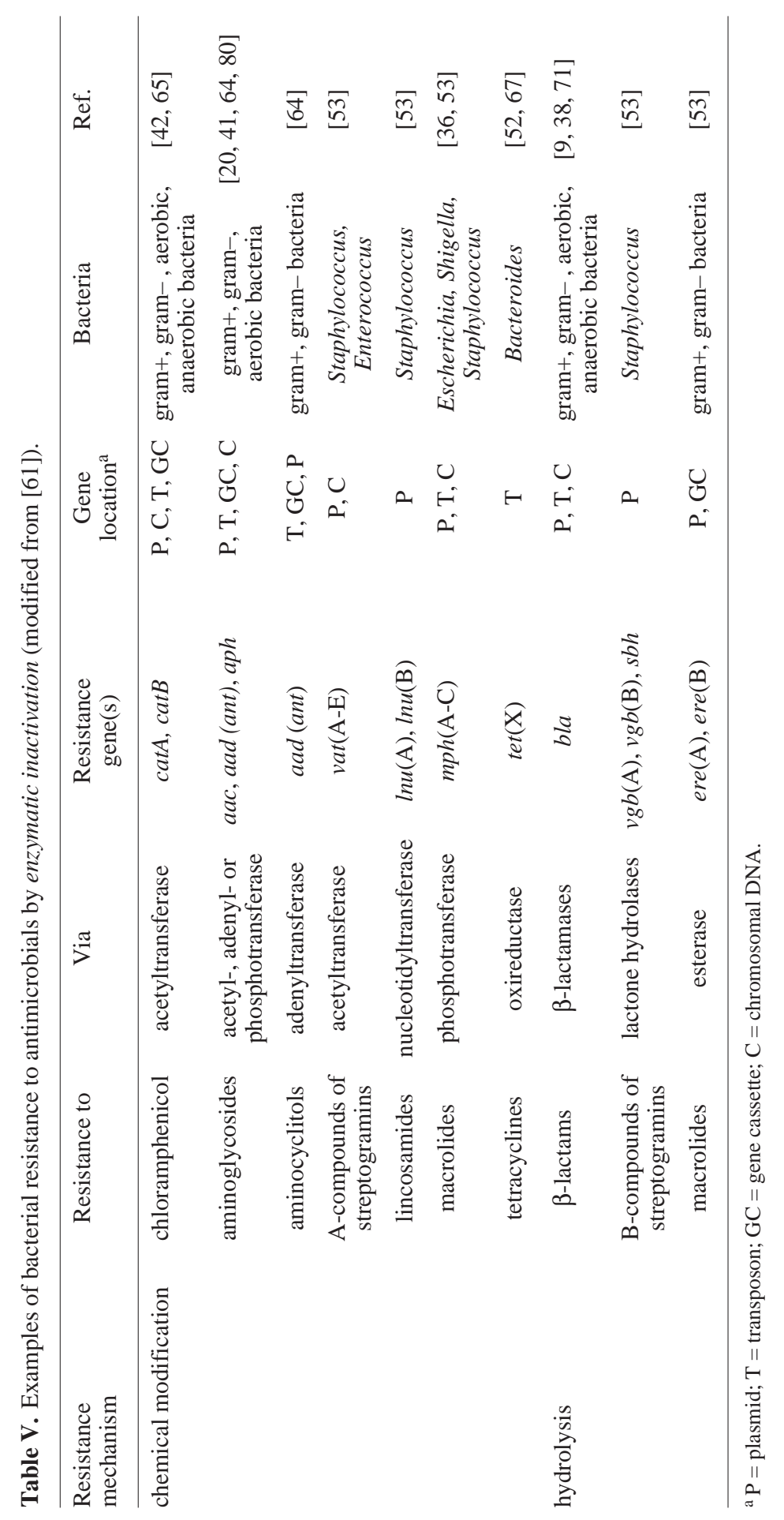


in addition to hydrophobic cations, detergents or nucleic acid binding compounds, has been largely observed [44, 47].

There are three major mechanisms by which bacteria have become resistant to antimicrobial agents: enzymatic inactivation as well as reduced intracellular accumulation of the antimicrobials, but also protection, alteration or replacement of the cellular target sites [2, 48, 61].

A wide variety of enzymes is known which inactivate antimicrobial agents by transferring acetyl, adenyl or phosphoric groups to specific sites of the antibiotics, thereby destroying their antimicrobial activity. Other enzymes, such as $\beta$-lactamases, hydrolases and esterases directly attack the antimicrobial molecule and destroy it. The substrate spectrum of inactivating enzymes is usually limited to a small number of structurally related compounds (Tab. V).

Reduced intracellular accumulation of antimicrobials can be achieved in principle in two different ways: decreased uptake or increased removal of the drugs. Decreased drug uptake is not usually mediated by resistance genes. The outer membrane of gramnegative bacteria may represent a permeability barrier for certain antibiotics [59]. Mutations are known which cause reduced expression, structural alteration or even loss of porins by which antibiotics enter the bacterial cell [48]. A switch in the charge of the cell wall lipopolysaccharides (LPS) has been reported in Pseudomonas aeruginosa to prevent highly positively charged antibiotics, such as aminoglycosides, from crossing the outer membrane [59]. Resistance genes which code for a number of membrane-associated efflux proteins have been detected on plasmids, transposons or gene cassettes. Such efflux systems mostly export a narrow range of structurally related substrates from the bacterial cell by energydependent processes [44]. In contrast, there is also a large number of multidrug transporters known in gram-positive and gramnegative bacteria, most of which export a wide range of structurally heterogeneous toxic compounds including antimicrobial agents [44, 47] (Tab. VI).

Chemical modification of the target site, e.g. by methylation, may render the target site inaccessible to the antibiotics [35]. Protection of the target sites, such as the ribosome, by specific protective proteins which are considered to inhibit binding of antimicrobials have been reported in connection with tetracycline resistance [52]. The overexpression of sensitive target structures, but also the replacement of sensitive target structures by new targets which exhibit reduced affinity for - or even insensitivity to - the antimicrobials represent other ways for the bacteria to resist the inhibitory activities of antimicrobials [48]. Moreover, a number of mutations in the genes coding for target structures which render the corresponding gene products resistant to the inhibitory effects of the antimicrobial agents have been identified (Tab. VII).

\section{RESISTANCE TO \\ ANTIMICROBIALS USED \\ IN VETERINARY MEDICINE}

\subsection{Resistance to tetracyclines}

So far, several different mechanisms of tetracycline resistance have been described, among which active efflux and ribosome protection are the most prevalent mechanisms among gram-positive and gram-negative pathogens [52].

The energy-dependent efflux of tetracyclines is mediated by at least two types of transmembrane proteins, both of which exchange a proton for a tetracycline-cation complex [52]. On the basis of hybridisation experiments, at least 14 different classes can be differentiated [37]. Among them, the most intensively studied classes are A, B, $\mathrm{C}, \mathrm{D}, \mathrm{H}, \mathrm{K}$, and $\mathrm{L}$. The genes $\operatorname{tet}(\mathrm{K})$ and tet $(\mathrm{L})$ are mainly present in gram-positive bacteria and code for a protein which 


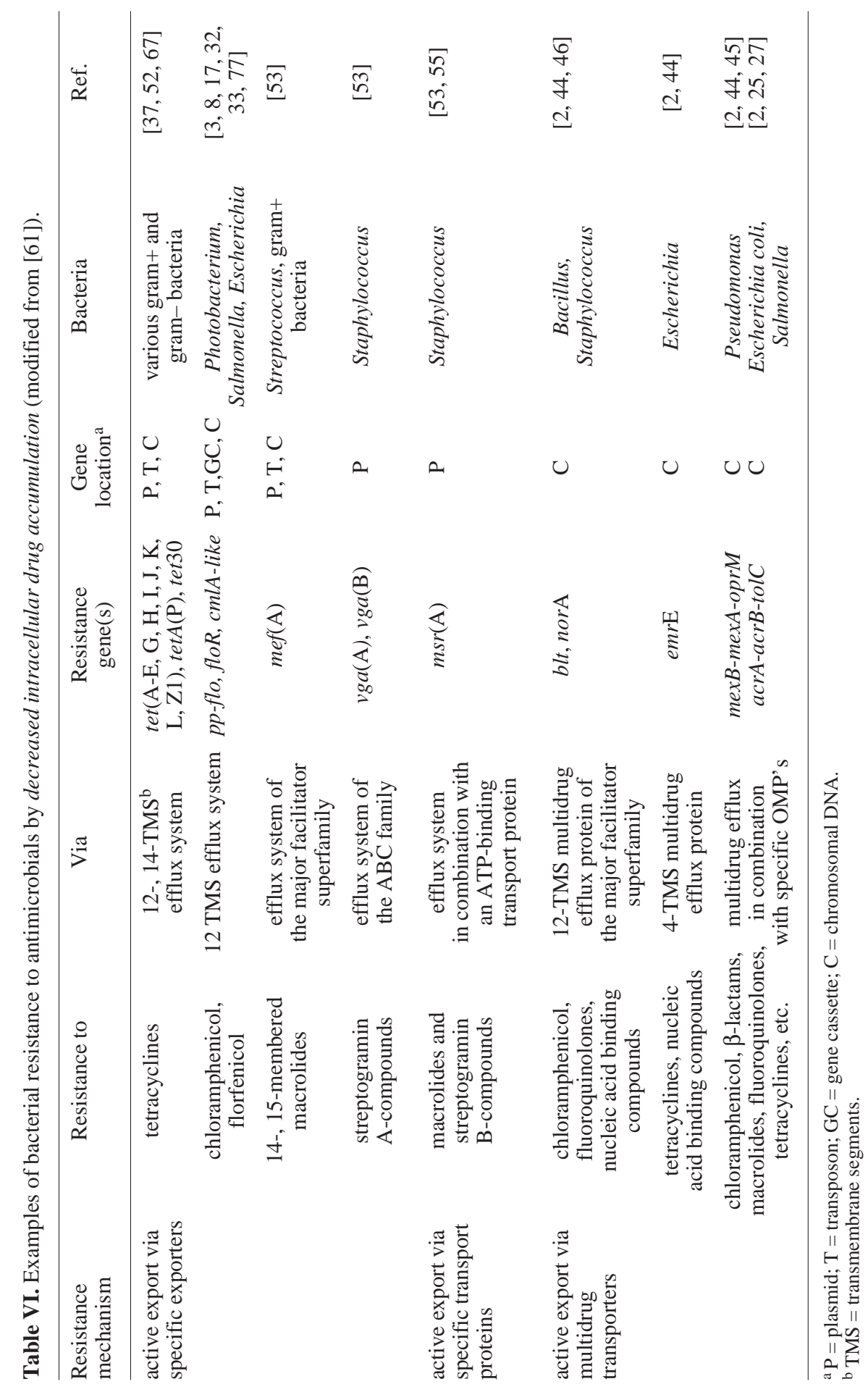




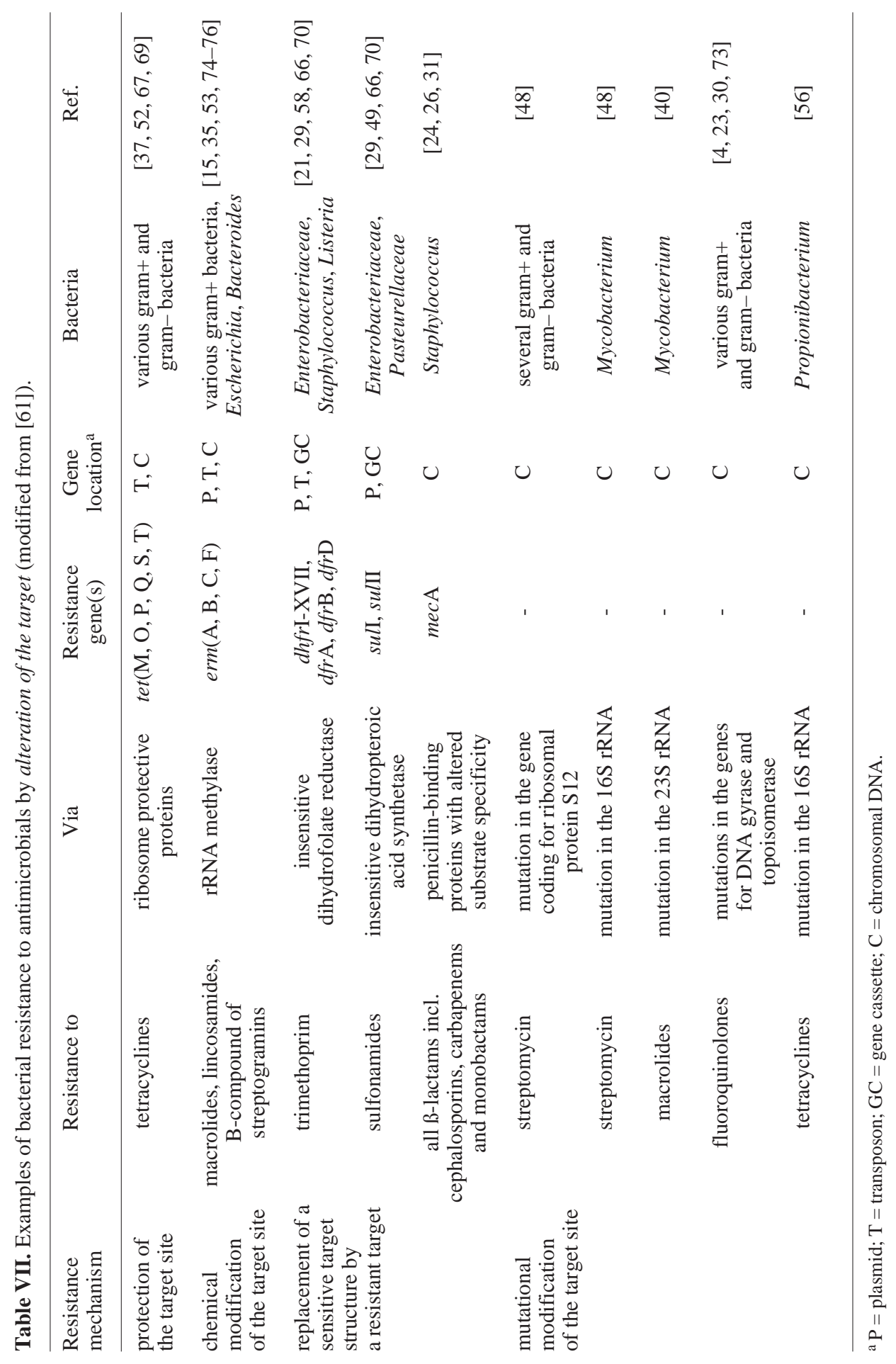


consists of 14 transmembrane regions. Their Tc-inducible expression is regulated by a mechanism known as "translational attenuation". Genes of classes K and L are frequently found on small plasmids which in rare cases may be integrated into other plasmids or into the chromosomal DNA, but may also undergo interplasmidic recombination with other resistance plasmids. The tetracycline efflux proteins present in gramnegative bacteria exhibit only 12 transmembrane segments. To date, eight different tet genes for efflux proteins in gram-negative bacteria, tet $(\mathrm{A}-\mathrm{E}, \mathrm{G}, \mathrm{H})$ and tet $(\mathrm{J})$, have been sequenced. Each of these tet structural genes is accompanied by a specific tet repressor gene. Tc-inducible expression of these tet genes is based on the binding of a tetracycline $\mathrm{Mg}^{2+}$ complex to the tet repressor protein which, in the absence of tetracycline, blocks transcription of the tet structural gene [52]. The tet genes of classes $\mathrm{C}, \mathrm{E}$, and $\mathrm{G}$ are often found on plasmids while those of classes $\mathrm{A}, \mathrm{B}, \mathrm{D}$, and $\mathrm{H}$ are associated with non-conjugative transposons or transposon-like elements which may also reside on plasmids.

The ribosome protective proteins identified so far share considerable homology with ribosomal elongation factors and also exhibit GTPase activity [69]. Until now, eight different classes of tet genes which code for ribosome protective proteins, $\mathrm{M}$, $\mathrm{O}, \mathrm{P}, \mathrm{Q}, \mathrm{S}, \mathrm{T}, \mathrm{W}$ as well as otrA, are known [37]. Tc-inducible expression of genes tet $(\mathrm{M})$ and $\operatorname{tet}(\mathrm{O})$ seems to be regulated at the transcription level. The tet $(\mathrm{M})$ gene is commonly found on conjugative transposons which exhibit an extremely broad host range. Thus tet $(\mathrm{M})$ genes are known to occur in a wide variety of gram-positive and gramnegative bacteria [52]. Genes of class $\mathrm{O}$ have mainly been detected in Campylobacter, Streptococcus, Enterococcus, and those of class $\mathrm{S}$ are present in Listeria and Enterococcus. The tet $(\mathrm{Q})$ gene has been shown to be part of large conjugative transposons in Bacteroides and related genera. The gene of class $\mathrm{T}$ has so far only been detected in
Streptococcus pyogenes and that of class W in Butyrivibrio fibrisolvens and other ruminal bacteria. The otrA gene which originated from tetracycline-producing Streptomyces spp. was also found in mycobacteria [52].

Only the tet gene of class X has been found to be involved in the inactivation of tetracyclines. The TetX protein represents a cytoplasmic protein that chemically modifies tetracycline in the presence of oxygen and $\mathrm{NADPH}$. Surprisingly, the tet $\mathrm{X}$ gene has not been detected in bacteria other than anaerobic Bacteroides spp. where the TetX protein is inactive [52, 67].

Different types of multidrug transporters mediating resistance to tetracycline in addition to resistance to a number of structurally unrelated compounds have been described, for instance, in Escherichia coli (EmrE), Salmonella (AcrAB/TolC) and Pseudomonas aeruginosa (MexAB/OprM; MexCD/OprJ) [44, 47].

A permeability barrier due to the reduced production of the OmpF porin by which tetracyclines cross the outer membrane has been described in Escherichia coli. Mutations in the marRAB operon which also regulates $\mathrm{OmpF}$ expression may play a role in this type of tetracycline resistance [48].

A mutation in the $16 S$ rRNA has been identified in Propionibacterium acnes [56] as conferring tetracycline resistance. This mutation consisted of a single base exchange $(1058 \mathrm{G} \rightarrow 1058 \mathrm{C})$. The position 1058 is located in a region known as helix 34 which plays an important role in the termination of peptide chain elongation as well as in the accuracy of translation.

\subsection{Resistance to macrolides, lincosamides, and streptogramins (MLS)}

Many gram-negative bacilli exhibit intrinsic resistance to the therapeutically achievable concentrations of macrolides and 
lincosamides, based on the reduced permeability of the outer membrane to these substances [48]. The mechanisms involved in resistance to macrolides, lincosamides and streptogramins so far observed mainly among gram-positive bacteria include target modification, active efflux and enzymatic inactivation $[35,36,53]$.

Target modification by rRNA methylases has been detected in a wide variety of grampositive but also several gram-negative bacteria. It is commonly due to the expression of a plasmid- or transposon-borne erm gene whose gene product dimethylates a specific adenine residue (A2058) in a conserved region of the $23 \mathrm{~S}$ rRNA $[35,74]$. This methylation confers cross-resistance to macrolides, lincosamides and B-compounds of streptogramins MLS $_{\mathrm{B}}$ antibiotics). Expression of the erm genes may be constitutive or inducible via translational attenuation; the type of expression depends on a regulatory region upstream of the $\mathrm{erm}$ gene [75]. Sequence deletions, duplications, and point mutations in the regulatory regions of certain $\mathrm{erm}$ genes have been found to cause a switch from inducible to constitutive expression [76]. At least 22 different classes of erm genes have been identified, four of which $-\mathrm{A}, \mathrm{B}, \mathrm{C}$, and $\mathrm{F}$ - also play a role in veterinary pathogens [53]. A summary of the genera in which the different $\mathrm{erm}$ genes have so far been detected has recently been published [53]. Genes of class A and B are part of non-conjugative or conjugative transposons, while genes of class $\mathrm{C}$ are commonly located on small plasmids up to $4 \mathrm{kbp}$ [53]. The $\operatorname{erm}(\mathrm{F})$ gene has been described as part of conjugative transposons in $\mathrm{Bac}$ teroides spp. [50]. A recent survey on the distribution and host range of the $\operatorname{erm}(\mathrm{F})$ gene has shown that this gene is widely distributed among gram-positive and gramnegative bacteria of medical and veterinary importance [15].

At least ten different efflux/transport systems have been described to confer resistance to members of the MLS group of antibiotics, four of which have been iden- tified among staphylococci and other grampositive pathogens while the remaining ones have been detected in soil bacteria of the genus Streptomyces [53]. These efflux/transport systems differ from one another in their substrate spectra. The gene $\operatorname{erp} \mathrm{A}$ is involved in the active efflux of 14- and 15-membered macrolides. The gene $m s r(\mathrm{~A})$ and its close relatives $m s r(\mathrm{SA}), m s r(\mathrm{SA})$ ' and $m s r(\mathrm{~B})$ code for ATP-binding transport proteins which mediate the active efflux of 14-membered macrolides and B-compounds of the streptogramins. Genes vga(A) and $v g a(\mathrm{~B})$ also code for ATP-binding transport proteins which, however, are involved in the export of A-compounds of the streptogramins. Most of the genes for these transport proteins are located on plasmids. Since the Msr and Vga proteins do not display the topology of membrane proteins, it is assumed that they interact with a membraneassociated $\mathrm{ABC}$-transporter. One such transporter with which MsrA may interact has been identified [55]. In addition to these transport proteins, another two closely related genes, mef(A) and $m e f(\mathrm{E})$, which code for efflux proteins involved in the export of macrolides were detected in members of the genera Streptococcus, Enterococcus, Staphylococcus and Corynebacterium. The Mef proteins exhibit homology to the major facilitator family of efflux proteins [53].

Enzymatic inactivation of MLS antibiotics is mediated by a number of different enzymes, each of which displays a narrow substrate spectrum $[36,53]$. Three different types of inactivating enzymes are known: esterases, hydrolases, and transferases. Among the esterases, two genes, ere(A) and ere(B) are known to occur mainly in Enterobacteriaceae. An esterase is also believed to confer resistance to 14and 16-membered macrolides in a clinical strain of Staphylococcus haemolyticus. Lactone hydrolases, encoded by genes $v g b(\mathrm{~A})$ and $v g b(\mathrm{~B})$ inactivate $\mathrm{B}$-compounds of the streptogramins. Acetyltransferases, encoded by genes vat(A-E) inactivate A-compounds 
of the streptogramins while nucleotidyltransferases encoded by $\ln u(\mathrm{~A})$ and $\ln u(\mathrm{~B})$ inactivate lincosamides. Phosphotransferases such as those encoded by genes $m p h(\mathrm{~A})$ and $m p h(\mathrm{~B})$ have been detected in Escherichia coli, the phosphotransferase encoded by mph(C) in Staphylococcus. Most of the genes for inactivating enzymes are associated with plasmids.

Mutations in the 23S rRNA associated with resistance to macrolides have been described in members of the genus Mycobacterium [40].

\subsection{Resistance to $\beta$-lactam antibiotics}

Resistance to $\beta$-lactam antibiotics is mainly mediated by a large number of $\beta$-lactamases which differ in their abilities to hydrolyse the various $\beta$-lactam antibiotics $[2,9,38,71]$. Other resistance mechanisms include the acquisition of penicillinbinding proteins (PBPs) with reduced affinity to $\beta$-lactams, mutations in the PBPs [24, 26 ], but also reduced $\beta$-lactam uptake due to alterations in the outer membrane of gramnegative bacteria or export by multidrug transporters [44, 48].

Enzymatic inactivation of $\beta$-lactam antibiotics is achieved by $\beta$-lactamases $[2,9$, $38,71]$. On the basis of their substrate spectra and their inhibition by clavulanic acid (CA), $\beta$-lactamases are classified into at least four classes (1-4), one of which, class 2, consists of eight subclasses [9]. It is noteworthy that single amino acid exchanges may result in changes of the substrate spectrum. The most frequently occurring $\beta$-lactamases are those of classes $1,2 \mathrm{a}$, $2 \mathrm{~b}$, and $2 \mathrm{be}$. Class $1 \beta$-lactamases (e.g. AmpC) represent cephalosporinases which are insensitive to inhibition by $\mathrm{CA}$. The respective bla genes are located on plasmids or in the chromosomal DNA. The $\beta$-lactamases of classes 2a, $2 b$ (e.g. TEM-1, TEM-2, SHV-1, ROB-1) and 2be (e.g. TEM-3 - 27; SHV-2 - 7; K1) hydrolyse either penicillins, penicillins and cephalosporins, or penicillins, cephalosporins and monobactams, respectively. Members of these three subclasses are sensitive to inhibition by CA, and their bla genes are mainly located on plasmids. The $\beta$-lactamases of class 2c (e.g. PSE-1, 3, 4; BRO-1,2) represent CAsensitive penicillinases. Class $2 \mathrm{~d} \beta$-lactamases (e.g. PSE-2; OXA-1 - 11) exhibit relative resistance to $\mathrm{CA}$ and are capable of hydrolysing penicillins, cephalosporins and oxacillin. Class 2 f (e.g. IMI-1) and class 3 (e.g. IMP-1; L1) $\beta$-lactamases are both able to hydrolyse penicillins, cephalosporins, monobactams and carbapenems, however, they differ in their sensitivity to CA: class $2 \mathrm{f}$ enzymes are sensitive while class 3 enzymes are resistant. The $\beta$-lactamases of class 4 hydrolyse penicillins and are resistant to inhibition by CA. Only $\beta$-lactamases of class $2 \mathrm{a}$ are present in gram-positive bacteria, as all other $\beta$-lactamases are found mainly among gram-negative bacteria. The $\beta$-lactamases of gram-negative bacteria are released into the periplasmic space while $\beta$-lactamases of gram-positive bacteria are secreted from the cell. With the exception of a few class 1 enzymes, most $\beta$-lactamases of gram-negative bacteria are constitutively expressed whereas class $2 \mathrm{a} \beta$-lactamases of gram-positive bacteria are usually inducibly expressed [48].

The acquisition of $\beta$-lactam-resistant PBPs which replace $\beta$-lactam sensitive PBPs is the cause of methicillin resistance in Staphylococcus aureus [24, 26]. Methicillinresistant Staphylococcus aureus (MRSA) isolates are resistant not only to all penicillins, but also to cephalosporins, carbapenems, and monobactams. The mecA gene which codes for $\beta$-lactam-resistant PBPs is located on a $52 \mathrm{kbp}$ genetic element designated Staphylococcus cassette chromosome mec (SSCmec) [31]. PBPs which exhibit low affinity for $\beta$-lactams have also been detected in streptococci and enterococci [48].

Reduced uptake of $\beta$-lactams as observed in Escherichia coli may be based on the decreased expression or the structural 
alteration of the porins $\mathrm{OmpF}$ and $\mathrm{OmpC}$ by which $\beta$-lactams pass through the outer membrane. In Pseudomonas aeruginosa, resistance to imipenem has been shown to be based on the loss of the porin OprD [48].

Multidrug transporters such as the MexAB/OprM export system in Pseudomonas aeruginosa [44], AcrAB/TolC in Salmonella and E. coli [47] can also mediate the excretion of $\beta$-lactams.

\subsection{Resistance to aminoglycosides}

Resistance to aminoglycosides is mainly based on enzymatic inactivation by aminoglycoside-modifying enzymes [64]. Moreover, decreased uptake of aminoglycosides and chromosomal mutations conferring high-level resistance to streptomycin have also been described [48].

Enzymatic inactivation of aminoglycosides is conferred by $\mathrm{N}$-acetyltransferases, $\mathrm{O}$-adenyltransferases or O-phosphotransferases [64]. There are numerous members of each of these three classes of aminoglycoside-modifying enzymes, most of which exhibit a specific substrate spectrum. A summary of the known aminoglycoside-modifying enzymes and their molecular relationships was published in 1993 [64]. However, since then, several new aminoglycoside-inactivating enzymes have been identified, some of which are part of integrons / gene cassettes [51]. Four classes of $\mathrm{N}$-acetyltransferases (AACs) are known which acetylate the amino groups at positions 1-, 3-, 2' - and 6' [20, 41, 64, 80]. To date, at least 16 different AACs have been identified, most of which were found in gram-negative bacteria [80]. Resistance to apramycin used in veterinary medicine only emerged after the introduction of this drug [13], in Salmonella and E. coli in animals; later on, a limited diffusion in hospitals was studied [12, 14]. All the known AAC variants differ in their substrate spectra. A bifunctional enzyme which codes for acetyltransferase AAC(6') and phosphotransferase
APH(2') activities was found on transposon Tn4001 which is widely spread among staphylococci and enterococci [57]. Most aac genes are located on plasmids, transposons or integrons. Five classes of O-adenyltransferases (ANTs) which act at positions $6,9,4$ ', 2', and 3' ' are differentiated $[20,41,64,80]$. The different ANT enzymes also show distinct differences in their substrate spectra. The various ant genes are mostly associated with either plasmids or transposons. Among the phosphotransferases (APHs) which phosphorylate the hydroxyl groups at positions 4, 6, 3', 2', and 3', at least 11 variants have been identified. Some of these aph genes are located on mobile genetic elements [20, 41, 64, 80]. The different APH variants also differ in their substrate profiles.

Decreased drug uptake of aminoglycosides has been described to be based on a mutation in LPS phosphates or on a change in the charge of the LPS in Escherichia coli and Pseudomonas aeruginosa, respectively [59]. Since the entry of aminoglycosides across the cytoplasmic membrane is mainly based on the electron transport system, anaerobes and facultative anaerobes exhibit relative resistance to aminoglycosides [48].

Mutations in either the gene for the ribosomal protein S12 or 16S rRNA have been described in connection with streptomycin resistance [48].

Efflux systems such as AcrD in Escherichia coli [54] and MexXY in Pseudomonas [1] have recently been described.

\subsection{Resistance to sulfonamides and trimethoprim}

Sulfonamides and trimethoprim block different enzymatic steps in tetrahydrofolate biosynthesis. Sulfonamides are structural analogs of $p$-aminobenzoic acid and competitively inhibit the enzyme dihydropteroic acid synthetase (DHPS) while trimethoprim competitively inhibits the 
enzyme dihydrofolate reductase (DHFR). While some bacteria are intrinsically resistant, acquired resistance may be due to chromosomal mutations or to plasmid-encoded DHPS or DHFR enzymes which are resistant to sulfonamides and trimethoprim, respectively $[2,21,48,70]$. A detailed description of the molecular basis of resistance to trimethoprim and sulfonamides was given by Sköld [66].

Intrinsic resistance to both compounds by outer membrane impermeability has been observed in Pseudomonas aeruginosa. Bacteria which can utilise exogenous folates such as enterococci and lactobacilli, also show intrinsic resistance to trimethoprim and sulfonamides. The DHFR enzymes of several bacterial genera including Clostridium, Neisseria, Brucella, Bacteroides and Moraxella exhibit low affinity for trimethoprim and thus render their hosts intrinsically resistant to trimethoprim [48].

Chromosomal mutations that cause an overexpression of $p$-aminobenzoic acid and/or DHFR can result in sulfonamide and/or trimethoprim resistance [48]. Mutations in the genes for DHPS and DHFR can reduce the affinity of the respective gene products for sulfonamides and trimethoprim, respectively. Moreover, mutational inactivation of the thymidylate synthetase which causes thymine auxotrophy results in resistance to folate pathway antagonists [48].

The replacement of sensitive enzymes by resistant enzymes usually causes high-level resistance [29]. Two resistant DHPS enzymes encoded by genes sulI and sulII have been described in gram-negative bacteria $[2,29,48]$. Gene sulI is part of class I integrons in transposon $\operatorname{Tn} 21$ which is often found on conjugative plasmids. The sulII gene occurs together with a streptomycin resistance gene on conjugative or non-conjugative plasmids [29, 49]. A number of different $d h f r$ genes have been described among gram-negative bacteria, several of which are part of gene cassettes [29]. In staphylococci, the composite transposon Tn4003 has been identified on various multiresistance plasmids [58]. Tn4003 is composed of a central $d f r$ A gene which codes for a DHFR enzyme with reduced affinity to trimethoprim, bracketed by copies of IS257. Another two trimethoprim resistance genes, $d f r B$ from $S$. haemolyticus and $d f r D$ from L. monocytogenes, have been encountered in gram-positive bacteria [11].

\subsection{Resistance to fluoroquinolones}

Resistance to fluoroquinolones is based either on mutations which render the target resistant to the drugs or on decreased intracellular drug accumulation [2, 23, 27, 48]. Enzymatic inactivation has not been observed so far. The molecular basis and epidemiology of quinolone resistance in E. coli and Salmonella was reviewed by Cloeckaert and Chaslus-Dancla [16], Webber and Piddock [73] and Bager and Helmuth [4], respectively.

Mutational alteration of the target structures mainly involves genes gyr A, gyr B (coding for DNA gyrase) and parC and parE (coding for DNA topoisomerase IV). A wide variety of mutations has been detected in the various target genes of a wide range of gram-positive and gram-negative bacteria of human and veterinary importance $[16,23,27]$. The effect of the different mutations on resistance also differs with respect to the various fluoroquinolones [30]. The gyrA mutations are commonly located within what is referred to as a quinolone resistance-determining region of $130 \mathrm{bp}$ [48].

Efflux systems conferring fluoroquinolone resistance have been identified in various gram-positive and gram-negative bacteria, such as Ps. aeruginosa (MexAB/OprM, MexCD/OprJ), S. aureus (NorA), S. pneumoniae (PmrA), B. subtilis (Blt), E. coli and Salmonella (AcrAB/TolC). For reviews, see references [16, 45-47]. Many of these efflux systems represent multidrug transporters 
which are able to export, in addition to quinolones, a wide range of other toxic substances from the bacterial cell [16, 44-46]. Since the basal level of expression of these efflux systems is low, upregulation of their expression is required to confer resistance to fluoroquinolones and other antimicrobials.

Decreased drug uptake in gram-negative bacteria is due to the MAR-mediated downregulation of OmpF porin production [48]. $\mathrm{OmpF}$ is an important porin for the entry of quinolones into the bacterial cell. Moreover, mutations in different gene loci $(c f x \mathrm{~B}, n o r \mathrm{~B}$, $n f x \mathrm{~B}, n o r \mathrm{C}$ or $n a l \mathrm{~B})$ are also associated with decreased permeability [28].

The relative involvement of these different mechanisms in the resistance to fluoroquinolones is questionable [3, 25, 43].

\subsection{Resistance to chloramphenicol and florfenicol}

Chloramphenicol resistance in grampositive and gram-negative bacteria is mainly due to enzymatic inactivation [2, 48]. Efflux systems which confer either only chloramphenicol resistance or combined resistance to chloramphenicol and florfenicol have also been described $[2,3,8,17$, $18,32,77]$. Permeability barriers and multidrug transporters only play a role in certain gram-negative bacteria $[44,48]$.

Enzymatic inactivation of chloramphenicol is due to chloramphenicol acetyltransferases (Cat) which are capable of transferring acetyl groups to the $\mathrm{C} 1$ and $\mathrm{C} 3$ positions of the chloramphenicol molecule; acetylated chloramphenicol derivatives cannot inhibit bacterial protein biosynthesis. Two different types of Cat enzymes are known: CatA and CatB enzymes. All CatA and $\mathrm{CatB}$ variants have a trimeric structure composed of three identical subunits, each of which ranges in size between 207 and 238 amino acids $[42,65]$. The cat gene codes for a Cat monomer. Expression of the mostly plasmid-borne catA genes found in Staphy- lococcus, Streptococcus, Enterococcus, Bacillus, and Listeria is inducible by chloramphenicol via translational attenuation [39]. Several catA genes identical or closely related to those of the $S$. aureus plasmids pC221, pC223/pSCS7 or pC194 have been detected in various staphylococci, but also in Streptococcus, Bacillus or Listeria, respectively [61]. The catA genes of Clostridium spp. are constitutively expressed. Three different types of constitutively expressed catA genes, designated I-III, have been detected in Enterobacteriaceae [65]. Gene catAI is located on the non-conjugative transposon Tn9 and related transposons. The gene catAII has been detected in Haemophilus spp. while the catAIII gene was present in Enterobacteriaceae and Pasteurella. The $c a t B$ genes - also referred to as xat (xenobiotic acetyltransferase) genes - differ distinctly from the catA genes in their sequences, but appear to be related to other genes such as vat(A-E), coding for acetylating enzymes involved in streptogramin resistance [42]. The first cat $B$ gene was detected in Agrobacterium tumefaciens, but others have been found on transposon Tn2424 in E. coli, on transposon Tn840 from Morganella morganii and in the chromosome of Ps. aeruginosa. Incomplete sequences of further catB genes from Serratia marcescens, $B$. sphaericus and S. aureus have been reported [42] and suggest a wider distribution of $c a t B$ genes among gram-positive and gram-negative bacteria than initially assumed.

Decreased intracellular chloramphenicol accumulation may result from mutations that cause reduced expression of a major outer membrane protein in Haemophilus influenzae and of the OmpF protein in Salmonella typhi $[2,48]$. Specific chloramphenicol exporters as encoded by genes $\mathrm{cmlA}$ and $\mathrm{cmlB}$ have been detected in Pseudomonas aeruginosa and Rhodococcus fascians [44]. The cmlA1 gene which is located on transposon Tn1696 has also been identified as part of a gene cassette [51]. Multidrug transporter systems in Pseudomonas 
aeruginosa, such as MexAB/OprM and MexCD/OprJ, also export chloramphenicol [44]. Genes, such as pp-flo and floR - coding for membrane-associated efflux systems which export chloramphenicol and florfenicol - have been detected on a plasmid in Photobacterium damselae subsp. piscicida [33] as part of a chromosomal multiresistance gene cluster in Salmonella enterica serovars Typhimurium [3, 8] and Agona [18], but also on multiresistance plasmids of $E$. coli [17, 32, 77].

Moreover, the plasmid-borne gene, $c f r$, from Staphylococcus sciuri has been found to mediate combined resistance to chloramphenicol and florfenicol by a yet unidentified mechanism [62].

\section{CONCLUSION}

The data presented in this review show that bacteria of the different species and genera have developed a wide variety of resistance genes to escape the inhibitory effects of antimicrobial agents. The relatively short time periods between the introduction of an antimicrobial agent into clinical use and the occurrence of resistant bacteria confirms that bacteria are able to quickly and efficiently adapt to altered environmental conditions caused by the widespread use of antimicrobials. In this regard, bacteria have also developed highly efficient ways to transfer resistance genes between members of different species and genera. These transfer systems allow a rapid exchange of resistance genes within bacterial mixed populations commonly seen on the skin but also on the mucosal surfaces of respiratory, alimentary and genito-urinary tract of humans and animals. The detection of the same resistance gene in a wide variety of bacteria (for an example see the distribution of tet genes as described in [52]) illustrates that such transfer systems involving mobile genetic elements are effectively used under in vivo conditions. In addition, bacteria have also developed a number of mutations which render their cellular target sites resistant to the respective antimicrobial agents. Three key factors with regard to the emergence of antimicrobial resistance have to be taken into account: (i) the association of the resistance gene(s) with mobile genetic elements, (ii) the close contact between bacteria in a polymicrobial environment, and (iii) the selective pressure as imposed by the use of antimicrobials. This latter aspect is the one which can effectively be influenced by all those people in human and veterinary medicine who prescribe and use antimicrobial agents. Bearing in mind that no new classes of antimicrobial agents are to be expected for veterinary use in the near future, every effort must be undertaken to retain the efficacy of those substances currently available. Since every use of antimicrobial agents may select for resistant bacteria, resistance development among bacteria is a physiological stress response to changes in their environmental conditions. We cannot avoid resistance development, but we can dramatically slow down the development and spread of resistance properties. Therefore, guidelines have been published by numerous national and international boards to assist all those people involved in the effort towards a prudent and judicious use of antimicrobials. Sticking to these guidelines will minimise the risk of selecting resistant bacteria during the therapeutic use of antimicrobials and in fact appears to be the only broad scale approach to retain the efficacy of antimicrobial agents for the control of bacterial infections in animals.

\section{REFERENCES}

[1] Aires J.R., Köhler T., Nikaido H., Plésiat P., Involvement of an active efflux system in the natural resistance of Pseudomonas earuginosa to aminoglycosides, Antimicrob. Agents Chemother. 43 (1999) 2624-2628.

[2] Alekshun M.N., Levy S.B., Bacterial drug resistance: response to survival threats, in: Storz G., Hengge-Aronis R. (Eds.), Bacterial stress 
responses, ASM Press, Washington D.C., 2000, pp. 323-366.

[3] Arcangioli M.-A., Leroy-Sétrin S., Martel J.-L., Chaslus-Dancla E., A new chloramphenicol and florfenicol resistance gene flanked by two integron structures in Salmonella typhimurium DT104, FEMS Microbiol. Lett. 174 (1999) 327-324.

[4] Bager F., Helmuth R., Epidemiology of quinolone resistance in Salmonella, Vet. Res. 32 (2001) 285-290.

[5] Bennett P.M., The spread of drug resistance, in: Baumberg S., Young J.P.W., Wellington E.M.H., Saunders J.R. (Eds.), Population Genetics in Bacteria, University Press, Cambridge, 1995, pp. $317-$ 344.

[6] Boatman M., Survey of antimicrobial usage in animal health in the European union, Boatman consulting, Sept. 1998, by order of FEDESA.

[7] Bories G., Louisot P., Rapport concernant l'utilisation d'antibiotiques comme facteurs de croissance en alimentation, Rapport présenté au Ministère de l'Agriculture, de la Pêche et de l'Alimentation, 1998, 23 p.

[8] Briggs C.E., Fratamico P.M., Molecular characterization of an antibiotic resistance gene cluster of Salmonella typhimurium DT104, Antimicrob. Agents Chemother. 43 (1999) 846-849.

[9] Bush K., Jacoby G.A., Medeiros A.A., A functional classification scheme for $\beta$-lactamases and its correlation with molecular structure, Antimicrob. Agents Chemother. 39 (1995) 1211-1233.

[10] Carattoli A., Importance of integrons in the diffusion of resistance, Vet. Res. 32 (2001) 243-259.

[11] Charpentier E., Courvalin P., Emergence of the trimethoprim resistance gene $d f r D$ in Listeria monocytogenes BM4293, Antimicrob. Agents Chemother. 41 (1997) 1124-1136.

[12] Chaslus-Dancla E., Martel J.L., Carlier C., Lafont J.P., Courvalin P., Emergence of aminoglycoside 3-N-acetyltransferase IV in Escherichia coli and Salmonella typhimurium isolated from animals in France, Antimicrob. Agents Chemother. 29 (1986) 239-243.

[13] Chaslus-Dancla E., Glupczynski Y., Gerbaud G., Lagorce M., Lafont J.P., Detection of apramycin resistant Enterobacteriaceae in hospital isolates, FEMS Microbiol. Lett. 52 (1989) 261-265.

[14] Chaslus-Dancla E., Pohl P., Meurisse M., Marin M., Lafont J.P., High genetic homology between plasmids of human and animal origins conferring resistance to the aminoglycosides gentamicin and apramycin, Antimicrob. Agents Chemother. 35 (1991) 590-593.

[15] Chung W.O., Werckenthin C., Schwarz S., Roberts M.C., Host range of the ermF rRNA methylase gene in human and animal bacteria, J. Antimicrob. Chemother. 43 (1999) 5-14.
[16] Cloeckaert A., Chaslus-Dancla E., Mechanisms of quinolone resistance in Salmonella, Vet. Res. 32 (2001) 291-300.

[17] Cloeckaert A., Baucheron S., Flaujac G., Schwarz S., Kehrenberg C., Martel J.-L., Chaslus-Dancla E., Plasmid-mediated florfenicol resistance encoded by the floR gene in Escherichia coli isolated from cattle, Antimicrob. Agents Chemother. 44 (2000) 2858-2860.

[18] Cloeckaert A., Sidi Boumedine K., Flaujac G., Imbrechts H., D'Hooghe I., Chaslus-Dancla E., Occurrence of a Salmonella enterica serovar Typhimurium DT104-like antibiotic resistance gene cluster including the floR gene in S. enterica serovar Agona, Antimicrob. Agents Chemother. 44 (2000) 1359-1361.

[19] Davies J., Inactivation of antibiotics and the dissemination of resistance genes, Science 264 (1994) 375-381.

[20] Davies J., Wright G.D., Bacterial resistance to aminoglycoside antibiotics, Trends Microbiol. 5 (1997) 375-382.

[21] Elwell L.P., Fling M.E., Resistance to trimethoprim, in: Bryan L.E. (Ed.), Microbial Resistance to Drugs, Springer Verlag, Berlin, 1989, pp. 249290.

[22] European Agency for the Evaluation of Medical Products (EMEA), Antibiotic resistance in the European union associated with therapeutic use of veterinary medicines. Report and qualitative risk assessment, by the committee for veterinary medicinal products, 1999 (http://www.eudra.org/ vetdocs/PDFs/ General/034299en.pdf).

[23] Everett M.J., Piddock L.J.V., Mechanisms of resistance to fluoroquinolones, in: Kuhlmann J., Dalhoff A., Zeiler H.-J. (Eds.), Quinolone antibacterials, Springer Verlag Berlin Heidelberg, 1998, pp. 259-296.

[24] Georgeopapadakou N.H., Penicillin-binding proteins and bacterial resistance to ß-lactams, Antimicrob. Agents Chemother. 37 (1993) 2045-2053.

[25] Giraud E., Cloeckaert A., Kerboeuf D., ChaslusDancla E., Evidence for active efflux as the primary mechanism of resistance to ciprofloxacin in Salmonella enterica serovar Typhimurium, Antimicrob. Agents Chemother. 44 (2000) 12231228.

[26] Hackbarth C.J., Chambers H.F., Methicillinresistant staphylococci: genetics and mechanism of resistance, Antimicrob. Agents Chemother. 33 (1989) 991-994.

[27] Hooper D.C., Mechanisms of fluoroquinolone resistance, Drug Res. Updates 2 (1999) 38-55.

[28] Hooper D.C., Wolfson J.S., Bozza M.A., Ng E.Y., Genetics and regulation of outer protein expression by quinolone resistance loci $n f x \mathrm{~B}, n f x \mathrm{C}$, and $c f x \mathrm{~B}$, Antimicrob. Agents Chemother. 36 (1992) 1151-1154.

[29] Huovinen P., Sundström L., Swedberg G., Sköld O., Trimethoprim and sulfonamide resistance, 
Antimicrob. Agents Chemother. 39 (1995) 279289.

[30] Jones M.E., Sahm D.F., Martin N., Scheuring S., Heisig P., Thornsberry C., Köhrer K., Schmitz F.-J., Prevalence of gyrA, gyrB, parC, and parE mutations in clinical isolates of Streptococcus pneumoniae with decreased susceptibilities to different fluoroquinolones and originating from worldwide surveillance studies during the 1997-1998 respiratory season, Antimicrob. Agents Chemother. 44 (2000) 462-466.

[31] Katayama Y., Ito T., Hiramatsu K., A new class of genetic element, Staphylococcus cassette chromosome mec, encodes methicillin resistance in Staphylococcus aureus, Antimicrob. Agents Chemother. 44 (2000) 1549-1555

[32] Keyes K., Hudson C., Maurer J.J., Thayer S., White D.G., Lee M.D., Detection of florfenicol resistance genes in Escherichia coli isolated from sick chickens, Antimicrob. Agents Chemother. 44 (2000) 421-424.

[33] Kim E.H., Aoki T., Sequence analysis of the florfenicol resistance gene encoded on the transferable R-plasmid of a fish pathogen, Pasteurella piscicida, Microbiol. Immunol. 40 (1996) 665-669.

[34] Kokjohn T.A., Transduction: Mechanism and potential for gene transfer in the environment, in: Levy S.B., Miller R.V. (Eds.), Gene transfer in the environment, McGraw-Hill, New York, 1989, pp. 73-97.

[35] Leclercq R., Courvalin P., Bacterial resistance to macrolide, lincosamide, and streptogramin antibiotics by target modification, Antimicrob. Agents Chemother. 35 (1991) 1267-1272

[36] Leclercq R., Courvalin P., Intrinsic and unusual resistance to macrolide, lincosamide, and streptogramin antibiotics in bacteria, Antimicrob. Agents Chemother. 35 (1991) 1273-1276.

[37] Levy S.B., McMurry L.M., Barbosa T.M., Burdett V., Courvalin P., Hillen W., Roberts M.C., Rood J.I., Taylor D.E., Nomenclature for new tetracycline resistance determinants, Antimicrob. Agents Chemother. 43 (1999) 1523-1524.

[38] Livermore D.M., $\beta$-Lactamases in laboratory and clinical resistance, Clin. Microbiol. Rev. 8 (1995) 557-584.

[39] Lovett P.S., Translational attenuation as the regulator of inducible cat genes, J. Bacteriol. 172 (1996) 1-6.

[40] Meier A., Kirschner P., Burkhardt S., Steingrube V.A., Brown B.A., Wallace Jr. R.J., Böttger E.C., Identification of mutations in 23S rRNA gene of clarithromycin-resistant Mycobacterium intracellulare, Antimicrob. Agents Chemother. 38 (1994) 381-384

[41] Mingeot-Leclercq M.-P., Glupczynski Y., Tulkens P.M., Aminoglycosides: activity and resistance, Antimicrob. Agents Chemother. 43 (1999) 727737
[42] Murray I.A., Shaw W.V., $O$-acetyltransferases for chloramphenicol and other natural products, Antimicrob. Agents Chemother. 41 (1997) 1-6.

[43] Oethinger M., Kern W.V., Jellen-Ritter A.S., McMurry L.M., Levy S.B., Ineffectiveness of topoisomerase mutations in mediating clinically significant fluoroquinolone resistance in Escherichia coli in the absence of the AcrAB efflux pump, Antimicrob. Agents Chemother. 44 (2000) 10-13.

[44] Paulsen I.T., Brown M.H., Skurray R.A., Protondependent multidrug efflux systems, Microbiol. Rev. 60 (1996) 575-608.

[45] Poole K., Efflux-mediated resistance to fluoroquinolones in Gram-negative bacteria, Antimicrob. Agents Chemother. 44 (2000) 2233-2241.

[46] Poole K., Efflux-mediated resistance to fluoroquinolones in Gram-positive bacteria and the mycobacteria, Antimicrob. Agents Chemother. 44 (2000) 2595-2599.

[47] Putman M., van Veen H.W., Konings W.N., Molecular properties of bacterial multidrug transporters, Microbiol. Mol. Biol. Rev. 64 (2000) 672-693.

[48] Quintiliani R. Jr., Sahm D.F., Courvalin P., Mechanisms of resistance to antimicrobial agents, in: Murray P.R., Baron E.J., Pfaller M.A., Tenover F.C., Yolken R.H. (Eds.), Manual of Clinical Microbiology, 7th ed., ASM Press, Washington D.C., 1999, pp. 1505-1525.

[49] Radström P., Swedberg G., RSF1010 and a conjugative plasmid contain sulII, one of two known genes for plasmid-borne sulfonamide resistance dihydropteroate synthase, Antimicrob. Agents Chemother. 32 (1988) 1684-1692.

[50] Rasmussen J.L., Odelson D.A., Macrina F.L., Complete nucleotide sequence and transcription of ermF, a macrolide-lincosamide-streptogramin $\mathrm{B}$ resistance determinant from Bacteroides fragilis, J. Bacteriol. 168 (1986) 523-533.

[51] Recchia G.D., Hall R.M., Gene cassettes: a new class of mobile element, Microbiology 141 (1995) 3015-3027.

[52] Roberts M.C., Tetracycline resistance determinants: mechanisms of action, regulation of expression, genetic mobility, and distribution, FEMS Microbiol. Rev. 19 (1996) 1-24.

[53] Roberts M.C., Sutcliffe J., Courvalin P., Jensen L.B., Rood J., Seppälä H., Nomenclature for macrolide and macrolide-lincosamide-streptogramin B resistance determinants, Antimicrob. Agents Chemother. 43 (1999) 2823-2830.

[54] Rosenberg E., Ma D., Nikaido H., AcrD of Escherichia coli is an aminoglycoside efflux pump, J. Bacteriol. 182 (2000) 1754-1756.

[55] Ross J.I., Eady E.A., Cove J.H., Baumberg S., Identification of a chromosomally encoded ABCtransport system with which the staphylococcal erythromycin exporter MsrA may interact, Gene 153 (1995) 93-98 
[56] Ross J.I., Eady E.A., Cove J.H., Cunliffe W.J., 16S rRNA mutation associated with tetracycline resistance in a Gram-positive bacterium, Antimicrob. Agents Chemother. 42 (1998) 1702-1705.

[57] Rouch D.A., Byrne M.E., Kong Y.C., Skurray R.A., The aacA-aphD gentamicin and kanamycin resistance determinant of Tn4001 from Staphylococcus aureus: expression and nucleotide sequence analysis, J. Gen. Microbiol. 133 (1987) 3039-3052.

[58] Rouch D.A., Masserotti L.J., Loo L.S.L., Jackson C.A., Skurray R.A., Trimethoprim resistance transposon Tn4003 from Staphylococcus aureus encodes genes for a dihydrofolate reductase and thymidylate synthetase flanked by three copies of IS257, Mol. Microbiol. 3 (1989) 161-175.

[59] Salyers A.A., Whitt D.D., Bacterial pathogenesis: a molecular approach, ASM Press, Washington D.C., USA, 1994.

[60] Salyers A.A., Shoemaker N.B., Stevens A.M., Li L.-Y., Conjugative transposons: an unusual and diverse set of integrated gene transfer elements, Microbiol. Rev. 59 (1995) 579-590.

[61] Schwarz S., Noble W.C., Aspects of bacterial resistance to antimicrobial agents used in veterinary dermatological practice, Vet. Dermatol. 10 (1999) 163-176

[62] Schwarz S., Werckenthin C., Kehrenberg C., Identification of a plasmid-borne chloramphenicol-florfenicol resistance gene from Staphylococcus sciuri, Antimicrob. Agents Chemother. 44 (2000) 2530-2533.

[63] Schwarz S., Kehrenberg C., Walsh T.R., Use of antimicrobial agents in veterinary medicine and food animal production, Int. J. Antimicrob. Agents 17 (2001) 431-437.

[64] Shaw K.J., Rather P.N., Hare S.R., Miller G.H., Molecular genetics of aminoglycoside resistance genes and familial relationships of the aminoglycoside-modifying enzymes, Microbiol. Rev. 57 (1993) 138-163.

[65] Shaw W.V., Chloramphenicol acetyltransferase: enzymology and molecular biology, Crit. Rev. Biochem. 14 (1983) 1-46.

[66] Sköld O., Resistance to trimethoprim and sulfonamides, Vet. Res. 32 (2001).

[67] Speer B.S., Shoemaker N.B., Salyers A.A., Bacterial resistance to tetracyclines: mechanisms, transfer, and clinical significance, Clin. Microbiol. Rev. 5 (1992) 387-399.

[68] Stanisich V.A., Identification and analysis of plasmids at the genetic level, in: Grinsted J., Bennett P.M. (Eds.), Plasmid Technology, Academic Press, London, 1988, pp. 11-48.

[69] Taylor D.E., Chau A., Tetracycline resistance mediated by ribosomal protection, Antimicrob. Agents Chemother. 40 (1996) 1-5.

[70] Then R.L., Mechanisms of resistance to trimethoprim, the sulfonamides, and trimethoprim-sulfamethoxazole, Rev. Infect. Dis. 4 (1982) 261269.

[71] Theuretzbacher U., $\beta$-Lactamases and $\beta$-lactamase inhibitors, Chemother. J. 7 (1998) 136-142.

[72] Ungemach F.R., Figures on quantities of antibacterials used for different purposes in the EU countries and interpretation, Acta Vet. Scand. Suppl. 93 (2000) 89-97.

[73] Webber M., Piddock L.J.V., Quinolone resistance in Escherichia coli, Vet. Res. 32 (2001) 275-284.

[74] Weisblum B., Erythromycin resistance by ribosome modification, Antimicrob. Agents Chemother. 39 (1995) 577-585.

[75] Weisblum B., Insights into erythromycin action from studies of its activity as inducer of resistance, Antimicrob. Agents Chemother. 39 (1995) 797-805.

[76] Werckenthin C., Schwarz S., Westh H., Structural alterations in the translational attenuators of constitutively expressed erm(C) genes, Antimicrob. Agents Chemother 43 (1999) 1681-1685.

[77] White D.G., Hudson C., Maurer J.J., Ayers S., Zhao S., Lee M.D., Bolton L., Foley T., Sherwood J., Characterization of chloramphenicol and florfenicol resistance in Escherichia coli associated with bovine diarrhea, J. Clin. Microbiol. 38 (2000) 4593-4598.

[78] Witte W., Klare I., Antibiotikaresistenz bei bakteriellen Infektionserregern: Mikrobiologischepidemiologische Aspekte, Bundesgesundheitsblatt - Gesundheitsforschung - Gesundheitsschutz 42 (1999) 8-16.

[79] Woodward K.N., Maximum residue limits - The impact of the UK and the EC legislation. Recent advances in animal nutrition, 1993, pp. 165-172.

[80] Wright G.D., Aminoglycoside-modifying enzymes, Curr. Opin. Microbiol. 2 (1999) 499503. 